Artigos 



\section{A ética de andar nas ruas do Rio de Janeiro}

Bruno Martins Carvalho

Em seu ensaio "A Ponte e a Porta", Georg Simmel argumenta que, ao designar as coisas como "separadas", nós já as relacionamos em nossa consciência: a porta representaria então como separar e conectar o que são dois lados de um mesmo ato. É difícil não pensar o Rio de Janeiro como "cidade partida" - porém, o ato de separar, contido na quase onipresente oposição entre "morro" e "asfalto" no imaginário coletivo, só parece apagar de nossas consciências o quanto os problemas e condições de um "lado" estão conectados aos do outro.

Como conciliar, portanto, a segregação sócio-espacial - onde desigualdades econômicas se manifestam de forma clara na geografia da cidade - com uma produção cultural que parece privilegiar ou se nutrir de misturas, repleta de figuras notórias pela capacidade de circular entre espaços diversos? João do Rio visitando a favela, Manuel Bandeira no velório de Sinhô, Chiquinha Gonzaga no palácio do Catete, Noel Rosa nos sambas do Estácio ou Hélio Oiticica na Mangueira - e hoje, o Maracanã, a praia, o funk das favelas que conquista a Zona Sul ou a classe média frequentando as escolas de samba permanecem tão emblemáticos de uma cultura ou identidade carioca quanto a realidade da violência urbana, e a imagem da cidade partida. ${ }^{1}$

Há também toda uma tradição literária de personagens "andarilhos", flâneurs fictícios ou cronistas que percorrem tanto as zonas centrais quanto periféricas da antiga capital: Elisiário em "Um Erradio" (1894), de Machado de Assis, Ricardo Coração dos Outros em Triste Fim de Policarpo Quaresma (1911), de Lima Barreto, e mesmo João do Rio, nas crônicas de A Alma Encantadora das Ruas (1908), poderiam todos ser vistos como "criaturas fronteiriças que não tem fronteiras" (Simmel, 2004, p. 69). Eles não devem ser entendidos, entretanto, como "pontes" entre os pólos sociais - afinal, como observa o próprio Simmel, as pontes pressupõem certa equivalência entre o ir e o vir, entre a direção dos fluxos, ao contrário das portas, que normalmente induzem à entrada, ${ }^{2}$ estabelecem fronteiras, ou podem ser usadas para barrar o acesso.

Nos exemplos citados acima, o fluxo dos intercâmbios e os espaços de negociação costumam ser desiguais, restritos (frequentemente a práticas musicais) e temporários: enquanto a assimetria dessas relações não nos permite falar de pontes, pode servir como ponto de partida para repensarmos o lugar da literatura no Rio de Janeiro contemporâneo. Se representações cartográficas omitem a dinâmica das relações entre áreas empobrecidas e "nobres" de uma cidade, ${ }^{3}$ como pode o texto literário mapear de forma mais precisa não as "pontes" visíveis e transitáveis, mas as "portas" - os preconceitos ou possibilidades que determinam os parâmetros de mobilidade de uma pessoa - permeando o cotidiano de um lugar?

Rubem Fonseca situa o seu conto "A arte de andar nas ruas do Rio de Janeiro" com exatidão no espaço físico do Centro da antiga capital. Os trajetos de seus personagens são traçados através dos nomes de praças, prédios e ruas - alguns dos quais podemos 
imaginar como obscuros ou insignificantes não só para o leitor que desconhece o Rio de Janeiro, como para muitos dos que o habitam. O itinerário do protagonista $-\mathrm{o}$ andarilho-escritor Augusto, que tenta escrever um livro com o mesmo título do conto - evita os "extremos" pelos quais a cidade ficou conhecida: não há nem favelas, nem Leblon. Embora enfoque a mesma área que serviu de tema para tantos cronistas decimonônicos e de princípios do século vinte, ele não parece se encaixar nos moldes que o crítico antenado sugeriria de imediato: se o texto evoca o flâneur e a tradição do cronista urbano, é para distanciá-los da experiência de Augusto.

O meio urbano que ele habita impede a atitude e a postura daquele tão decantado ícone da modernidade parisiense. Saturada de "automóveis [que] batem uns nos outros", as ruas não mais convidam à caminhada contemplativa do flâneur: "[os automóveis] passam por cima das pessoas mais lentas ou distraídas" (FONSECA, 1992, p. 43). O narrador ressalta a perspectiva de quem anda a pé, onde andar - que deixa de ser o meio de transporte predominante - se configura quase como um ato excêntrico: "Como anda a pé, vê coisas diferentes de quem anda de carro, ônibus, trem, lancha, helicóptero ou qualquer outro veículo" (FONSECA, 1992, p. 18). A prática talvez ganhe maior relevância se lembrarmos de como estamos lidando com o início dos anos noventa: justo quando, em meio às reformas neoliberais, abre-se o mercado para a importação de automóveis importados, mais velozes e desejáveis.

Augusto também não parece pertencer à linhagem de cronistas que poderíamos associar ao autor citado na epígrafe, o Joaquim Manuel de Macedo de Um passeio pela cidade do Rio de Janeiro (1862-3): "Em uma palavra, a desmoralização era geral. Clero, nobreza e povo estavam todos pervertidos". A referência merece ser lida com certa dose de ironia pelo moralismo e recato que caracterizam o texto, tão distantes do "realismo feroz" e "brutalista" da literatura de Rubem Fonseca. ${ }^{4}$ Enquanto Macedo se detém nos monumentos (igrejas, praças) centrais e de interesse para o leitor "refinado", Augusto não discrimina o "feio" e nem estigmatiza os "pervertidos", engajando-se no bas-fond da cidade habitada por ratos, marginais, moradores de rua e prostitutas.

A área pode ser a mesma desde uma perspectiva cartográfica, mas passear pelos seus locais mais "civilizados" em meados do século dezenove significa algo inteiramente diferente de percorrer as ruas do Centro nos anos noventa do século seguinte, o que de fato requer uma certa arte. Entre os dois momentos - e ligado ao surgimento e consolidação das dicotomias entre "morro" e "cidade" que marcariam a psicologia e cotidianos cariocas - se dá o "bota-abaixo" (1904-1906) promovido por Pereira Passos para possibilitar a construção da Avenida Central, atual Rio Branco. No processo, como sabemos, muitos dos moradores de baixa renda expulsos dos cortiços e sobrados demolidos passaram a viver (em situação precária) nos morros adjacentes (Valladares). Assim, a população marginal(izada) nunca se manteve fisicamente distante da avenida que almejavam as elites políticas da Primeira República: excludente, "bela", e inspirada na Paris pós-Haussmann. ${ }^{5}$

Ao enfocar o Centro da década de noventa, desvalorizado desde os anos quarenta devido a uma série de fatores (políticas públicas, especulação imobiliária, etc.), Rubem Fonseca coloca em cena o periférico. O Centro decadente e abandonado, entretanto, não é condenado nem pelo narrador nem por Augusto - cujas vozes frequentemente se confundem 
nos muitos discursos indireto livres do texto. O tom da narrativa, assim como o que é descrito, pouco se assemelha à visão do Rio de Janeiro de Macedo, ou já após as reformas urbanas, à cidade da belle époque de cronistas como Olavo Bilac, Coelho Neto, ou mesmo Luiz Edmundo. É revelador que, para o leitor contemporâneo, por exemplo, o chavão "Cidade Maravilhosa" - usado para caracterizar o Rio após as reformas - dificilmente vá remeter à Avenida Rio Branco.

Ao contrário do precedente literário estabelecido pela epígrafe, portanto, “em suas andanças pelo centro da cidade, desde que começou a escrever o livro, Augusto olha com atenção tudo o que pode ser visto, fachadas, telhados, portas, janelas, cartazes pregados nas paredes, letreiros comerciais luminosos ou não, buracos nas calçadas, latas de lixo, bueiros, o chão que pisa, passarinhos bebendo água nas poças, veículos e principalmente pessoas" (FONSECA, 1992, p. 12). O narrador associa este olhar atento e inclusivo à condição de escritor ("desde que começou a escrever o livro"), insinuando talvez uma motivação ulterior. ${ }^{6}$ Augusto "anota o que vê ao caminhar pela cidade e escreve seu livro” (FONSECA, 1992, p. 16). É como se mapeasse as ruas de baixo para cima, numa inversão da ambição panóptica, no que o encontrado por Augusto (buraco, lixos, e logo ratos e mendigos) nega o impulso "civilizatório" por detrás do projeto literário de Macedo, assim como das reformas urbanas promovidas pela gestão de Rodrigues Alves e celebradas pela maioria dos cronistas da época.

Ao mesmo tempo, o conto não cria ilusões quanto ao poder transformativo da literatura. Um personagem secundário, João, colega de Augusto que trabalhava na "companhia de águas e esgotos" e "que havia publicado um livro de poesia e outro de contos", inclusive parece constituir uma espécie de paródia do poète maudit, apropriado por certa parcela da classe artística e por parte da crítica de alguns autores, principalmente Lima Barreto, que se posicionavam em oposição aos apologistas da belle époque de fachada, cristalizada na Avenida Central. ${ }^{8}$ Aqui, a expectativa do artista "maldito" é exposta ao ridículo ao invés de glamourizada ou sacralizada:

\footnotetext{
João dizia que havia um ônus a pagar pelo ideal artístico, pobreza, embriaguez, loucura, escárnio dos tolos, agressão dos invejosos, incompreensão dos amigos, solidão, fracasso. E provou que tinha razão morrendo de uma doença causada pelo cansaço e pela tristeza, antes de acabar seu romance de seiscentas páginas. Que a viúva jogou no lixo, junto com outros papéis velhos (FONSECA, 1992, p. 11-12).?
}

O Augusto escritor também não cumpre uma função didática, servindo como figura inspiradora ou exemplar. Ao contrário, quando ele tenta corrigir os erros ortográficos de dois jovens grafiteiros, por exemplo, o seu purismo linguístico soa igualmente ridículo. E se os próprios erros dos grafiteiros são caricaturais, a intervenção de Augusto acaba não sendo eficiente ou frutífera: "O jovem responde: 'Tio, você entendeu o que a gente quer dizer, não entendeu?, então foda-se com suas regrinhas de merda” (FONSECA, 1992, p. 19). Enquanto o personagem talvez não esteja a par do status decrescente da literatura e do escritor na cultura de massa do final do século, esta reconfiguração é evocada em algumas passagens do texto, nem sempre desprovidas de humor. Quando Augusto regressa ao seu apartamento, por exemplo, ouve de Kelly, uma prostituta que 
ele paga para ensinar a escrever: "Apareceu um rato e eu joguei um livro nele mas não consegui acertar" (FONSECA, 1992, p. 28), como se os livros estivessem relegados a esta última função utilitária.

O próprio fato de que Augusto precisa pagar para ensinar as prostitutas a ler é indicativo desta "nova ordem" cultural onde a literatura perde seu valor em relação à televisão, etc. Por outro lado, o conto não renega o poder da linguagem e o potencial da leitura como instrumento de subversão sócio-política ou apoderamento. Se Augusto, ao alfabetizar prostitutas exerce certo controle (como mecanismo compensativo para uma aparente impotência?), quando ele pergunta para Zumbi do Jogo da Bola, líder da União dos Desabrigados e Descamisados, "Você sabe ler?", a resposta inesperada inverte as relações de poder: "'Se não soubesse ler estava morando feliz dentro de uma caixa de papelão apanhando restos. [...] Acabou o papo Epifânio [nome verdadeiro de Augusto, seu pseudônimo]. [...] Pega tuas coisas e te manda"' (FONSECA, 1992, p. 46). A leitura, portanto, parece estar por detrás tanto da agência pela qual Zumbi clama quanto do movimento que ele organiza e chefia. Mas o mesmo não pode necessariamente ser dito sobre o que se convencionou chamar literatura, ou sobre o projeto literário. E afinal, nada nos garante que Zumbi esteja contando a verdade: sempre há a possibilidade de que ele de fato não saiba ler, o que só confirmaria o prestígio da leitura, e não necessariamente qualquer função conscientizadora.

Além das alusões irônicas beirando o pastiche, um dos procedimentos que desvincula Augusto dos precedentes citados é a referência explícita a uma tradição ambulante muito anterior ao flaneur baudelariano, ao cronista urbano e ao contexto das figuras "mediadoras" mencionadas na introdução deste ensaio: "[Augusto] acredita que ao caminhar pensa melhor, encontra soluções para os problemas; solvitur ambulando, diz para seus botões." (FONSECA, 1992, p. 11) O lema em latim solvitur ambulando, "resolve-se andando", remete ao filósofo grego Diógenes, o Cínico (412? - 323a.c.), sendo adotado por Santo Agostinho e toda uma tradição de peregrinação medieval cristã. ${ }^{10}$

Se Augusto habita a urbs pós-flâneur e já não inspira a crença na literatura como missão, tampouco pode ser visto como o indivíduo metropolitano blasédescrito por Simmel, indiferente à distinção entre as coisas, experimentando-as como insignificantes. Augusto demonstra ser capaz de emoções estéticas, e mesmo de preocupações éticas. Ele busca soluções, não para os seus problemas, mas para os problemas. Este comprometimento ético por si só, de certa forma, acerca-o do autor da epígrafe - ainda que eles tenham sensibilidades bastante distintas. O narrador começa definindo o que Augusto não quer que o seu livro seja:

Ele pretende evitar que seu livro seja uma espécie de guia de turismo para viajantes em busca do exótico, do prazer, do místico, do horror, do crime e da miséria, como é do interesse de muitos cidadãos de recursos, estrangeiros principalmente; seu livro também não será um desses ridículos manuais que associam o andar à saúde, ao bem-estar físico e às noções de higiene (FONSECA, 1992, p. 18-19). 
E, por fim, o telos (ou a techne?) que guia o escritor-andarilho é revelado: "Augusto quer encontrar uma arte e uma filosofia peripatéticas que o ajudem a estabelecer uma melhor comunhão com a cidade. Solvitur ambulando" (FONSECA, 1992, p. 19). É provável que a dimensão religiosa da palavra "comunhão" seja a primeira a vir em mente para o leitor de uma sociedade majoritariamente Católica. A narrativa, entretanto, contém uma série de críticas devastadoras às religiões institucionalizadas, particularmente cristãs: "O movimento da Igreja ecumênica é a cartelização dos negócios de superstição, um pacto de não-agressão entre mafiosos” (FONSECA, 1992, p. 25). A instituição religiosa, portanto, é despida de qualquer valor espiritual ou ético, antes equiparada à indústria do entretenimento, vide o "cinema-templo" dos cultos evangélicos (FONSECA, 1992, p. 12). Augusto, como veremos, "odeia Jesus Cristo" (FONSECA, 1992, p. 25) e a noção de "comunhão" aqui deve ser abordada por um ângulo mais abrangente.

O termo tem relação com o grego koinós, que antes da era Cristã significava "compartilhar", denotando uma coletividade. ${ }^{11}$ Koinós (e derivados, como koinonia) está conectado etimológicamente (através do latim) com conceitos aparentemente tão díspares quanto comunhão, comunicação, comunidade e mais recentemente comunismo (o prefixo co, con, com significa junto). A noção de koinós era essencial para o funcionamento da polis e convivia com os valores de individualismo tão caros à visão do mundo na Grécia Antiga. Koinotaton, na Retórica de Aristóteles, por exemplo, denota algo do público ou de interesse geral dos habitantes de uma comunidade. ${ }^{12}$

A cidade na literatura de Rubem Fonseca é um lugar onde qualquer resquício de koinós parece haver sido descartado. Ao invés de um sentido de comunidade, onde se compartilha, prevalecem as práticas do desperdício e da competição desenfreada: "uma cidade grande gasta muita água e produz muito excremento" (FONSECA, 1992, p. 11). Há um colapso de comunicação, uma "corrosão do diálogo", já apontada por Renato Cordeiro Gomes em sua leitura do conto (GOMES, 1994, 149-162). E a sugestão de um colapso (ou, ao menos, de um desequilíbrio) ecológico coincide com o fato de que a almejada "comunhão com a cidade" se realiza em contato com o pouco que resta da natureza no Centro da cidade. Em um dia em que "ele quer ver apenas as árvores" (FONSECA, 1992, p. 25) no Campo de Santana - antigo Campo da Aclamação e oficialmente Praça da República, cuja "velha história" Augusto demonstra conhecer — o andarilho protagoniza uma cena ao mesmo tempo grotesca e singela:

[...] Augusto entra até o ponto mais fundo da gruta, onde fica imóvel como uma pedra, ou melhor, uma árvore subterrânea. [...] Nunca ficou uma noite inteira dentro do Campo de Santana, já rodeou o campo à noite, namorando as árvores através das grades [...]. Na escuridão as árvores são ainda mais perturbadoras do que na claridade, e deixam que Augusto, ao caminhar lentamente sob suas sombras noturnas, comungue com elas como se fosse um morcego. Abraça e beija as árvores [...]. Entre as árvores Augusto não sente irritação, nem fome, nem dor de cabeça (FONSECA, 1992, p. 27).

Além de qualquer alusão velada à alegoria da caverna platônica - que aqui inverteria a subjugação do mundo dos sentidos ("das sombras") ao mundo das formas - a passagem oferece também uma "comunhão" ("as árvores [...] deixam que Augusto [...] comungue com elas") pouco frequente tanto entre os personagens de Rubem Fonseca quanto da literatura urbana em geral. 
Para Augusto, que nasceu e cresceu no Centro do Rio, esta relação com as árvores do Campo de Santana representa algo além da mera nostalgia por um tempo perdido. Ele integra as árvores na narrativa histórica da cidade, e elas servem como contraste para a velocidade das mudanças no espaço urbano: "mostra as árvores para Kelly, diz que elas têm mais de duzentos anos" (FONSECA, 1992, p. 30), "as mesmas daquele tempo longínquo [quando 'Dom Pedro foi aclamado imperador']". Augusto adota uma postura de veneração - "como sempre tem vontade de se ajoelhar ante as árvores mais antigas" (FONSECA, 1992, p. 25) - e mais adiante esta relação com as árvores enche "sua cabeça de um gás perfumado e invisível que ele sente, e que transmite tal leveza ao seu corpo que se ele tivesse a pretensão, e vontade arrogante, poderia até mesmo tentar voar" (FONSECA, 1992, p. 28). Porém, se obtém uma religação com um estado de pureza, esta transcendência é removida da matriz religiosa oficial. De fato, neste trecho da narrativa, ele volta abertamente a hostilizar a religião institucional, ligada ao mercantilismo: ele não se ajoelha ante as árvores porque "ficar de joelhos lembra a religião católica e ele agora odeia todas as religiões que fazem as pessoas ficarem de joelhos, e também odeia Jesus Cristo, de tanto ouvir os padres, os pastores, os eclesiásticos, os negociantes falarem nele" (FONSECA, 1992, p. 25).

Uma vez mais, o texto parece se inserir em modelos literários justamente para estabelecer distância: não há nada de romantizado nas cenas de Augusto com as árvores e na gruta - um lugar-comum do romantismo que lembra uma famosa cena de A Moreninha de Macedo, cujo protagonista também se chama Augusto - e o personagem de Rubem Fonseca, é claro, também não se encaixa em qualquer esquema pastoril ou bucólico. Antes, os gestos de Augusto podem ser interpretados como recursos ou impulsos quase desesperados (se não esdrúxulos) de (re)conectar com a natureza em meio à vida urbana. Talvez por isso ele seja comparado com um morcego (“[ ...] comungue [...] como um morcego") e com um rato ("bebe em pequenos goles, como um rato"), seres, além de tidos como "grotescos" (palavra etimologicamente conectada à gruta), sumamente urbanos - como nós. O resultado é que se Augusto não chega a representar a espécie de anti-herói típico da narrativa de Rubem Fonseca, ele tampouco serve como modelo de defensor da natureza. Suas ações, no máximo, podem ser vistas como sintomáticas do desejo de uma convivência com o mundo natural que não seja baseada na exploração desmedida e agressiva: que reconheça, afinal, o outro lado do ato de separar ser humano e natureza, reinserindo-nos no meio do qual somos parte integral.

A urgência da preocupação ecológica latente no conto independe de Augusto, podendo ser extraída também da menção implícita à ECO 92, encontro que o Rio de Janeiro sediou no ano de publicação do conto de Rubem Fonseca. Deduzimos que a este evento se refere o morador de rua Benevides: "Estão dizendo que vai ter aqui na cidade um grande congresso de estrangeiros e que vão querer esconder a gente dos gringos. Não quero sair daqui" (FONSECA, 1992, p. 35). Confirmando as suspeitas de Benevides, durante o evento a cidade foi transformada em uma espécie de vila de Potemkin, com presença militar e remoção de "elementos indesejados" das ruas para que a miséria não pudesse ser vista pelos ilustres dignitários "gringos". 
Esta preocupação de Benevides é articulada mais conscientemente e com maior ardor pelo homem que ele chama de Zé Galinha, mas que se apresenta como Zumbi do Jogo da Bola (Jogo da Bola sendo o nome de uma rua no Morro da Conceição). Ao contrário de Benevides, que não quer sair de sua situação de indigência, Zumbi reage contra a invisibilidade à qual a sociedade prefere condenar os "excluídos", aqueles - como ele - às margens dos sistemas de distribuição de riqueza:

Nós não pedimos esmolas, não queremos esmolas, exigimos o que tiraram da gente [...]. Queremos ser vistos, queremos que olhem a nossa feiúra, que sintam o nosso bodum em toda parte, que nos observem fazendo nossa comida, dormindo, fodendo, cagando os lugares bonitos onde os bacanas passeiam ou moram (FONSECA, 1992, p. 46).

$\mathrm{O}$ ato de se nomear Zumbi e não Zé Galinha já representa uma tentativa de reivindicar dignidade. Seu discurso também alia a revolta a certa lucidez, reproduzindo um conhecido argumento que costumamos ouvir daqueles que estão em posição de dar. Zumbi não quer esmolas, o que a longo prazo pode somente perpetuar a assimetria das relações de poder, estabelecendo um ciclo de dependência: quem dá se livra da "culpa" - ou dá porque "o santo pode estar notando" (FONSECA, 1992, p. 48) - e quem recebe é encorajado a se manter pedinte, subserviente. Zumbi também não quer ser transformado em mero "dado social" ou vítima do sistema, como se os que não têm alternativa senão morar nas ruas fossem uma abstração ou sub-humanos, e não pessoas que faz̧em comida, dormem, fodem, e cagam assim como os "bacanas [que] passeiam ou moram" nos "lugares bonitos". E em última instância, seu apelo ("queremos ser vistos") é também uma reação contra a vontade dos "bacanas" de esconder os "miseráveis".

Afinal, pode-se dizer que soluções cosméticas para problemas sistêmicos são quase a regra na história de políticas urbanas no Rio de Janeiro, e Fonseca distribui críticas sutis e informadas através do conto. O próprio desejo de Augusto de desvincular seu livro de "noções de higiene" poderia ser lido como uma maneira de alfinetar os discursos higienistas, utilizados para justificar as reformas urbanas durante a Primeira República. Nunca é demais lembrar que o urbanismo, enquanto disciplina, nasce de mãos dadas com o higienismo.

Além da tendência a negligenciar ou "esconder" a população indigente, encontramos referências ao descaso com a memória histórico-arquitetônica da cidade: "Vou te mostrar os três prédios [da avenida Rio Branco] que não foram demolidos" (FONSECA, 1992, p. 31). O desaparecimento progressivo de marcos físicos da cidade produz consequências intangíveis, como o "desenraizamento" dos que frequentam seus espaços. ${ }^{13}$ Ao lamentar como "antigamente havia botequins espalhados pela cidade" (FONSECA, 1992, p. 31) e relembrar a música de Noel Rosa, Augusto ouve a resposta de Kelly (de nome aptamente anglicizado): "Noel? Não é do meu tempo. Desculpe". Com os botequins, desaparece toda uma cultura oral-musical que neles se formou e neles perdura. A perda de símbolos coletivos (como Noel Rosa) e práticas compartilhadas (como a ida ao botequim) acarreta na corrosão do diálogo, refletido na forma abrupta como se dá o convívio entre os personagens do conto. 
Em relação ao planejamento urbano e à perda de um sentido de comunidade na cidade, Fonseca aponta ainda a negligência dos urbanistas pelas particularidades locais (climáticas, paisagísticas, etc.) ou pelo bem-estar dos habitantes sem-carro:

\footnotetext{
"[Augusto] desce pela Presidente Vargas maldizendo os urbanistas que demoraram dezenas de anos para perceber que uma rua larga daquelas precisava de sombra e só em anos recentes plantaram árvores, a mesma insensatez que os fizera plantar palmeiras-imperiais no canal do Mangue" (FONSECA, 1992, p. 28).
}

Como de costume nas obras de Rubem Fonseca, os detalhes aqui nada tem de ociosos - se alusões à Avenida Rio Branco trazem à tona o "bota-abaixo" de Pereira Passos, este trajeto evoca uma outra intervenção urbana drástica feita no Rio de Janeiro enquanto capital federal: a construção da Avenida Presidente Vargas durante o Estado Novo, em nome da qual grande parte do bairro da Cidade Nova foi destruído. Atravessá-la "é sempre perigoso, está sempre morrendo gente atropelada naquela rua" (FONSECA, 1992, p. 44).

O texto contém críticas conhecidas, sem entretanto incorrer no tom panfletário, sem os radicalismos que surgem da polarização ideológica. De fato, o próprio lema solvitur ambulando representa um apelo à praticidade, amplificado até por Augusto buscar não uma comunhão completa e perfeita com a cidade, mas uma "melhor comunhão" (19). Andar para ele também não é só uma atitude intelectual ou estratégia artística, é uma maneira de evitar assaltos à noite, quando existe um perigo quase constante no Centro: "Augusto manda a mulher [Kelly] andar, para não serem assaltados" (FONSECA, 1992, p. 22). Até aonde consta, não se trata de uma das preocupações do flâneur parisiense.

Essas práticas, nascidas da experiência direta de como a cidade funciona, podem servir como complemento às críticas implícitas ao caráter frequentemente ideológico dos planos urbanísticos, sugerindo como, ao contrário das respectivas reputações, às vezes os escritores-andarilho ou poetas têm uma noção mais concreta das condições sociais de um lugar do que tecnocratas que sequer percebem "estar nas nuvens." A lição não poderia ser mais simples: da observação direta, nasce o reconhecimento da complexidade dos problemas, primeira etapa em qualquer processo de "resolver-se".

Em um dos últimos diálogos do conto, e dos seus mais extensos, a conversa entre Augusto e o quase alegórico Velho (que repete, "vai ser tudo derrubado") revolve em torno do "sentido da vida", tema difícil de ser abordado em um texto contemporâneo sem que se deslize para o irônico, pomposo, ou clichê. Sendo a ironia uma qualidade de difícil apreensão para o crítico, talvez seja mais pertinente enfatizar as razões que Augusto e o Velho dão para continuar vivendo: "Por que você quer continuar vivendo?", pergunta o Velho. "Eu gosto das árvores. Quero acabar de escrever meu livro. [...]". [O Velho]: "Eu fico vivo porque não sinto muitas dores no corpo e gosto de comer [...]" (FONSECA, 1992, p. 49).

Escrever, árvores, comida e falta de dor são coisas concretas e desvalorizadas no meio urbano, onde imperam velocidade, competição e jogos de aparências. A narrativa, de certa maneira, requalifica como essencial aquilo que é tido por banal. Ao mesmo tempo, as limitações de um olhar cartográfico parecem ser intensificadas por peculiaridades geográficas e 
culturais do Rio de Janeiro, "uma cidade muito grande, guardada por morros, de cima dos quais pode-se abarcá-la, por partes, com o olhar, mas o centro é mais diversificado e obscuro e antigo [...]” (FONSECA, 1992, p. 16). Se mapas são representações estáticas da disposição de ruas e lugares no espaço (aquilo que "nenhum olho poderia jamais ver" para citar Christian Jacob), o texto de Rubem Fonseca registra as funções que um local acumula através do tempo: algo parecido com o que Michel de Certeau chamaria de récits d'espace. O narrador mapeia eventos e lugares de relevância no cotidiano do Centro, como os endereços de McDonald's (FONSECA, 1992, p. 20), por seus banheiros limpos e acessíveis, e um novo ponto de jogo do bicho (FONSECA, 1992, p. 23), lembrando tanto a onda neoliberal promovida pelo governo Collor (quando franquias norte-americanas expandem suas presenças no Brasil) quanto a força da informalidade na economia ("cada dia há mais pontos de jogo espalhados pela cidade”).

Vendo de cima, desde Santa Teresa, "não dá para se ter a menor ideia de como é o centro, não se vêem as calçadas das ruas, quando muito vê-se em certos dias o ar poluído pousado sobre a cidade" (FONSECA, 1992, p. 16). O texto deflagra, de certa forma, as impossibilidades de um olhar totalizante, assim como de soluções permanentes, e nos permite atribuir os fracassos da metrópole moderna (miséria, poluição, etc.) não aos limites da objetividade e às armadilhas de um empirismo científico, mas sim a uma certa desatenção ou mesmo desprezo dos que detêm poder de decisão (a determinada altura, urbanistas) pelo concreto, pelas contingências e potencialidades da vida diária no meio urbano. O olhar de Augusto, portanto, aliado ao solvitur ambulando, propõe uma "ethics of seeing" ligada não à fotografia (como na expressão de Susan Sontag), mas ao próprio andar, ao ato de circular a pé pelas ruas de uma cidade. ${ }^{14}$

No que (para repetir um lugar-comum) transformou-se em uma cultura sobretudo visual, onde predominam artefatos capazes de nos fazer testemunhar o distante (televisão, cinema, fotografia), ao mesmo tempo talvez nunca tenha sido tão fácil deixar de olhar o próximo - pelo menos para uma parcela da população que pode transitar pela cidade a bordo de carros e, quando não em velocidade, recorrer àquele hábito de cerrar os vidros no sinal fechado. No conto de Rubem Fonseca - cujo implied reader, presumimos, tem maior probabilidade de ser usuário de automóvel do que pedinte - a desconfiança é mútua. Benevides, por exemplo, morador de rua, achava que Augusto poderia ser policial (FONSECA, 1992, p. 34).

No contexto das distâncias físicas, sociais e psicológicas que marcam a cidade, a arte de andar nas ruas do Rio de Janeiro constitui-se em parte de alguma solução ("resolve-se andando") e o texto reveste-se de um sentido ético - evidente, inclusive, em preocupações como a de Augusto em evitar "uma espécie de guia de turismo para viajantes em busca do exótico, [...] do crime e da miséria”, antecipando a crítica ao voyeurismo dos favela tour. Se "as coisas precisam primeiro ser separadas para poderem estar juntas" (SIMMEL, 2004, p. 68), é como se a narrativa sugerisse que os leitores focassem o reverso do ato de separar contido na visão da cidade dividida.

O narrador, ao retratar o que Augusto vê, constata como o cotidiano carioca é feito de combinações à primeira vista inesperadas, complicando uma série de dicotomias aceitas: o gerente que deixa moradores de rua viverem ao lado do banco, o cinema que é templo de manhã e exibe filmes pornográficos à tarde, a família de brancos vivendo 
como agregados de negros, o culto evangélico incorporando samba-enredo e rock. Essas justaposições desarmam o leitor ao serem relatadas sem alarde - um pouco como a técnica kafkiana de narrar o fantástico com total naturalidade. Pois no caso deste conto, elementos que caracterizariam lados opostos do abismo social ou de uma moralidade convencional aparecem juntos não como forma de reconectar o "separado", mas como descrição realista do dia-a-dia de grande parte dos moradores da metrópole: a cidade do Rio, apesar de partida, também é porosa.

O fato de uma mesma sala de cinema ser ocupada por uma igreja e por filmes pornográficos, por exemplo, pouco tem de contraditório: adequa-se com total coerência na lógica capitalista. A maneira na qual o pensamento de Augusto não se estrutura em torno de dicotomias ou paradoxos - sua veia pragmática, quiçá - permite ao texto abordar questões sócio-econômicas espinhosas sem patrulhamento ideológico (de esquerda ou de direita) e sem diluí-las na salada do pós-modernismo. A narrativa, por exemplo, releva hierarquias sócio-raciais ao especificar que "Ana Paula é branca, assim como Marcelo é branco, e são apenas agregados da família de negros que controla aquela esquina" (31). Mas ao não submeter seus personagens às expectativas de o negro estar em situação pior que a do branco, o registro do narrador inclusive adquire uma textura mais verossímil, refletindo o grau de porosidade dentro da estratificação sócio-racial.

Ao mesmo tempo, atento à complexa dinâmica das relações de poder nas ruas, o conto se recusa a reduzir pessoas a meras estatísticas oficiais, ou em agentes do "bem" ou do "mal". O narrador não exotiza, mistifica nem esteriliza os hábitos da população que sobrevive precariamente nas ruas, e não demoniza nem exime o gerente "gente fina" (FONSECA, 1992, p. 34) que "deixa" Benevides e seu "clã" viverem em frente ao Banco Mercantil. Como em alguns dos melhores documentários, não há nem vilões absolutos nem vítimas puras. Há, entretanto, uma carregada dimensão ética. Aproximar os extremos aqui não equivale de forma alguma a celebrar encontros culturais, práticas sincréticas ou hibridismo. Muito pelo contrário: serve para expor o fato de que mesmo miseráveis e abastados convivem e compartem - ainda que não em pé de igualdade, e que sequer se vejam. Assim como a denúncia de Macedo abre o conto aproximando clero, nobreza e povo sob o signo da perversão, Fonseca os aproxima no contexto dos sistemas de produção e organização social - os mesmos que produzem as diferenças que atravessam a narrativa, onde leitores de barriga cheia se deparam com personagens reduzidos a viver de restos. Enquanto muito mudou entre os passeios de Macedo e de Augusto pelo Centro do Rio de Janeiro, também há continuidades.

Se, no fim do século dezenove, moradores expulsos do cortiço conhecido como "cabeça-de-porco" usavam materiais das demolições para erguer barracos no Morro da Providência (CHALHOUB, 1996, p. 17), os personagens do conto transformam em parede as tábuas de uma construção abandonada do metrô. Uma integrante do "clã" do Benevides, Ana Paula, "goza [do] conforto" de um outro barraco, uma caixa de papelão cuja origem o autor faz questão de especificar, subproduto do consumo burguês: trata-se da embalagem de uma geladeira grande.

Na metrópole descrita por Rubem Fonseca, os destituídos vivem do lixo produzido pelos privilegiados. Os moradores de rua competem para juntar papel ou garrafas de vidro e vendê-los por alguns trocados: e como Benevides diz para Augusto, "tem mendigo demais na 
cidade, apanhando papel, disputando o ponto com a gente" (FONSECA, 1992, p. 34). O estado precário da dignidade humana, em meio a este sistema onde uma parcela da população urbana depende daquilo que se "joga fora", transparece na última frase do conto: "É domingo, o dia surge cinzento; aos domingos a maioria dos restaurantes do centro não abre; como todo domingo, será um dia ruim para os miseráveis que vivem dos restos de comida jogados fora" (FONSECA, 1992, p. 50). Os "miseráveis" estão mais próximos de viver como ratos do que como gente, comparação que não seria um insulto para Augusto, que gosta dos ratos e os alimenta.

Ainda que o conto não apague divisões ou ignore diferenças, as perambulações de Augusto desconsideram os muros entre os lados da cidade, encontrando ou fabricando portas. Em termos formais, poderíamos conjeturar a própria narrativa - dividida em dez seções, entre as quais há um deslocamento espaço-temporal - como sendo peripatética, onde a “art de 'tourner' des phrases a pour équivalent l'art de tourner des parcours" (FONSECA, 1992, p. 151). E se, ao final, o conto apresenta ou mesmo performa qualquer "solução", isto não é articulado de maneira objetiva ou ortodoxa, em "linha reta", mas tal como Augusto se locomove: "continua em direção ao seu objetivo nesse dia, mas não em linha reta" (FONSECA, 1992, p. 24), ziguezagueando, apesar de que "ainda que pareça deambular, nunca anda exatamente ao léu” (FONSECA, 1992, p. 23). De forma análoga, "A arte de andar nas ruas do Rio de Janeiro", que "às vezes [se entrega] a divagações prolixas" (FONSECA, 1992, p. 19), com frases longas para os padrões fonsequianos, parece ter "objetivos" dissimulados e uma consciência ética latente.

No aparente pessimismo do texto, e em face da óbvia insuficiência da solução-andarilha perante problemas tão graves quanto os que o Rio de Janeiro enfrenta, despontam sugestões de novas estratégias. Percebe-se uma preocupação por estratégias no decorrer do conto, através de sátiras dos que não obtêm êxito: a tática de Hermenegildo, por exemplo, de grudar manifestos ecológicos contra o automóvel em pára-brisas de carros estacionados (FONSECA, 1992, p. 20). Enquanto andar já tem em si implicações positivas para o meio ambiente, a "solução" mais benéfica à qual o conto alude não surge de qualquer consciência ecológica, e sim da pobreza e do desemprego: se o Brasil está entre os países que mais reciclam latas de alumínio, é por causa de catadores como Benevides.

Mas o conto sugere ainda outra estratégia retórica, provavelmente mais útil em tempos de debates relacionados ao aquecimento global. O amanhecer que encerra a narrativa, um dia que surge cinzento e onde "as águas do mar fedem" (FONSECA, 1992, p. 50), lembra uma observação de Elizabeth Lowe de que "the city is a central metaphor and dynamic force in Fonseca's fiction; and into the microcosm of the Brazilian city he projects an apocalyptic vision of the human condition, recreating the myth of the Fall” (LOWE, 1982, p. 18). Este caráter apocalíptico no texto em questão ultrapassa não só a realidade sociológica retratada, como também transcende a matriz metafísico-religiosa do mito da Queda - podendo se tornar um comentário acerca das consequências drásticas de um modelo urbano predatório sobre o meio ambiente. $\mathrm{Na}$ imagem final da cidade, portanto, o apocalipse emerge como recurso retórico para efetuar sua própria descontinuação e prevenir sua realização. 
${ }^{1}$ Ainda que não seja o propósito deste ensaio, a celebração de encontros entre classes sociais e grupos raciais como espécie de característica carioca deve, é claro, ser inserida no contexto de fenômenos mais amplos como o mito ou ethos da democracia racial, o culto à mestiçagem e ao sincretismo, etc.

${ }^{2}$ Vide os portais de catedrais góticas ou romanescas no exemplo de Simmel, que tem a intenção de criar um efeito de induzir a um interior, levando a um espaço finito, ao contrário das pontes que costumam conectar espaços "infinitos".

${ }^{3}$ No caso do Rio, pensemos nas complexas redes de relações envolvendo empregadas domésticas, grades de condomínios, e tráfico de drogas, assim como nas intervenções estatais, presença de ONGs, e nas incursões policiais, jornalísticas e acadêmicas à favela, por exemplo. Os mapas da cidade tem inclusive um histórico de omitir as favelas, representando-as como massas indistinguíveis das áreas florestais (Carvalho).

${ }^{4}$ Antonio Candido descreve o estilo de Rubem Fonseca como de um "realismo feroz" (211), e Alfredo Bosi vê em Fonseca um estilo "brutalista" (18).

${ }^{5}$ As reformas uniam objetivos políticos e econômicos (melhorar a circulação de mercadorias, dissipar a reputação do Rio como "túmulo de estrangeiros") ao desejo das elites de transformar o Rio em uma Paris nos trópicos. A influência da Paris de Haussmann (cujas reformas se estendem de 1853 a 1870) transparece em como o concurso de fachadas impunha o estilo eclético francês então em voga. A euforia chegou a tal ponto que de acordo com relatos da época, os discursos da festa de inauguração, em 15 de novembro de 1905, eram entrecortados por gritos de "Vive la France!". A preocupação em "afrancesar" o Rio de certa forma acompanhava a vontade de "embranquecê-lo": algumas medidas, como a proibição de andar descalço ou sem paletó na Avenida Central, claramente visavam demarcar os espaços da elite, negando aos de baixa renda (frequentemente negros) o acesso à avenida. A bibliografia sobre as reformas é extensa (Sevcenko, Needell, Benchimol).

"A ideia de uma ligação entre o olhar "devorador" e a criação artística lembra a receita que um médico dá ao escritor vegetariano em outro conto de Romance negro e outras histórias, sugestivamente intitulado "Olhar": "A coisa mais criativa que o homem pode fazer é comer [...]. Arte é fome" (65).

${ }^{7} \mathrm{O}$ poeta Paul Verlaine cunhou a expressão em Les poètes maudits (1884), sua coleção de estudos sobre a (trágica) vida e obra dos até então desconhecidos poetas simbolistas.

${ }^{8}$ Ainda durante a construção da Avenida Central, Lima Barreto chamava Pereira Passos de "fachadista".

"O tema da escrita em um mundo mercantil é recorrente na obra de Rubem Fonseca: em "Intestino Grosso", por exemplo, conto da coletânea Feliz, Ano Novo (1975), o escritor e aparente alter ego do autor assume a escrita como ofício profissional, cobrando por cada palavra dita durante uma entrevista. O próprio Augusto, que só não precisa trabalhar porque ganhou na loteria, demonstra ter alguma preocupação financeira.

${ }^{10}$ A expressão aparece em referência às provas da possibilidade do movimento em Diógenes, sendo depois incorporada pela tradição romana e cristã, sempre como apelo à experiência prática na busca de soluções (Coleman). ${ }^{11}$ Já no terceiro século antes da era Cristã o termo começa a adquirir um significado distinto (koiné dialektos), denotando a língua comum do mundo helênico. Mesmo dentro dos evangelhos, seu significado ganha novos sentidos, eventualmente sendo traduzido (em latim) como algo ordinário ou vulgar.

${ }^{12}$ Em Liddel e Scott "koinotaton: of public or general interest, ib. 724b, cf. Arist. Rh. 1354b29"; Aristóteles figura mais diretamente no conto através do desejo de Augusto estabelecer uma "filosofiaperipatética", já que o sentido secundário do vocábulo remete ao filósofo grego.

${ }^{13}$ Renato Cordeiro Gomes argumenta que Augusto "tem a intenção de resgatar essa memória através do livro que escreve" e que ele anda "para escrever e restaurar a cidade pela letra" (151). Quando sua aluna Kelly, que desiste da vida de prostituta, suscita em Augusto um "amor fraterno" talvez dormente no indivíduo urbano, parece que ele anseia não pelo resgate de qualquer memória histórica, mas sim por um contato que torna o sofrimento ("dela e dele") mais suportável - restaurando o sentido de kómos latente na comunicação, e imprescindível para o funcionamento de uma comunidade.

${ }^{14}$ Latente nessa "ethics of seeing" do andar nas ruas, podemos extrair e articular uma crítica a um primeiro urbanismo (ainda vigente apesar de não mais hegemônico) cuja concepção da cidade partia de uma olhar "de cima" - vide os planos que Le Corbusier traça para a capital na década de 20, imaginados desde uma viagem de avião, e os projetos de Alfred Agache para o Rio (1930), que exigiram fotografias aéreas tiradas de balões. 


\section{Bibliografia}

ABREU, Maurício de Almeida. Evolução Urbana do Rio de Janeiro. Rio de Janeiro: J. Zahar Editor, 1987.

AGACHE, Donat Alfred. Cidade do Rio de Janeiro, extensão, remodelacao, embellezamento. Organisacao projectadas pela administracao, Antonio Prado Junior. Sob a direccao geral de Alfred Agache. Paris: Foyer brésilien, 1930.

BAUER, Walter, Wilbur Gingrich, e Frederick W. Danker, eds. A Greek-English Lexicon of the New Testament and Other Early Christian Literature. Chicago: University of Chicago Press, 1979.

BENCHIMOL, Jaime L. Pereira Passos: um Haussmann tropical: a renovação urbana da cidade do Rio de Janeiro no início do século XX. Rio de Janeiro: Departamento Geral de Documentação e Informação Cultural, 1990.

BOSI, Alfredo. "Situação e formas do conto brasileiro contemporâneo", in: O conto brasileiro contemporâneo. São Paulo: Cultrix, 1975.

CANDIDO, Antonio. "A nova narrativa”, in: A educação pela noite. São Paulo: Ática, 1987.

CARVALHO, Bruno. "Mapping the urbanized beaches of Rio de Janeiro: modernization, modernity, and everyday life", Journal of Latin American Cultural Studies, volume 17, December 2007.

CERTEAU, Michel de. L'invention du quotidien. Paris: Gallimard, 1990.

CHALHOUB, Sidney. Cidade febril: cortiços e epidemias na Corte imperial. São Paulo: Companhia das letras, 1996.

COLEMAN, Simom, e John Eisner. Pilgrimage: Past and Present in the World Religions. Cambridge: Harvard University Press, 1997.

FONSECA, Rubem. Romance negro e outras histórias. São Paulo: Companhia das Letras, 1992.

FONSECA, Rubem. Feliz, Ano Novo. Rio de Janeiro: Editora Artenova, 1975.

GOMES, Renato Cordeiro. Todas as cidades, a cidade. Rio de Janeiro: Rocco, 1994.

JACOB, Christian. L'empire des cartes: approche théorique de la cartographie à travers l'histoire. Paris: A. Michel, 1992.

KUSTER, Eliana e Robert Moses Pechman. "Da ordem. Da cidade. Da literatura: personagens à beira do 'ruim do mundo", Sociedade e Estado, vol. 22, set./dez. 2007.

LIDDELL, Henry George, and Robert Scott, eds. A Greek-English Lexicon. Oxford: Clarendon Press, 1940.

LOWE, Elizabeth. The City in Brazilian Literature. London: Associated University Presses, 1982.

MACEDO, Joaquim Manuel. Um Passeio pela Cidade do Rio de Janeiro. Rio de Janeiro: Garnier, 1991.

NEEDELL, Jeffrey D. A tropical belle epoque: elite culture and society in turn-of-the-century Rio de Janeiro. Cambridge: Cambridge University Press, 1987.

PEREIRA, Sonia Gomes. A reforma urbana de Pereira Passos e a construção da identidade carioca. Rio de Janeiro: UFRJ, 1992.

SEVCENKO, Nicolau. Literatura como Missão: Tensões Sociais e Criação na Primeira República. São Paulo: Brasiliense, 1989.

SIMMEL, Georg. "Bridge and Door". In: Rethinking Architecture: a reader in cultural theory. Ed. Neil Leach. Routledge: New York, 2004.

SONTAG, Susan. On photography. New York: Farrar, Straus and Giroux, 1977.

TESTER, Keith, ed. The Flâneur. London: Routledge, 1994.

VALLADARES, Licia do Prado. A invenção da favela: do mito de origem a favela.com. Rio de Janeiro: Editora FGV, 2005. 
